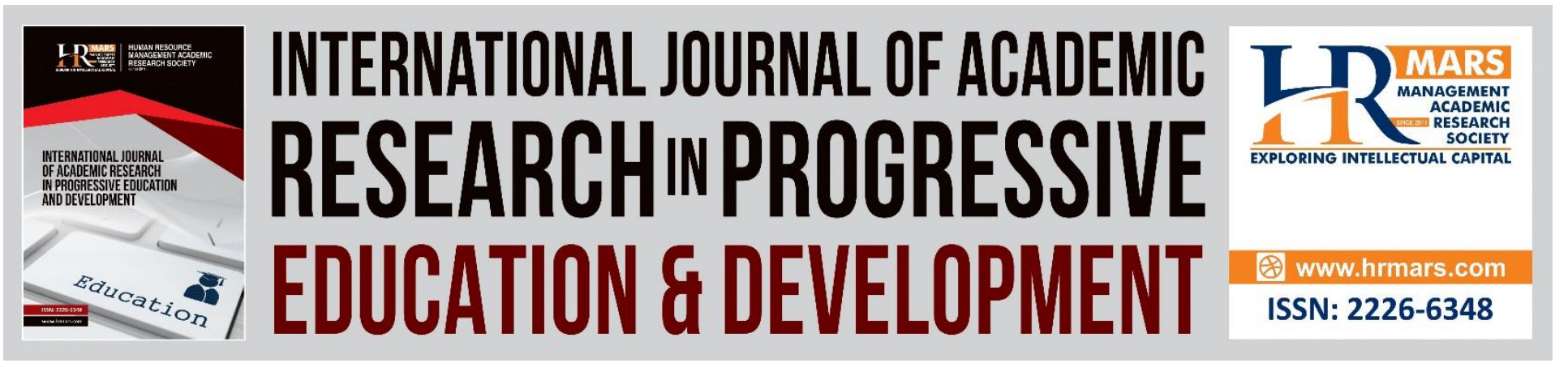

\title{
Homeschooling Effectiveness in Cultivating Islamic Values for Children: A Case Study at Mutiara Ummah Sidoarjo Homeschooling
}

Istikomah, Abdul Hakim Abdullah, Normadiah Daud, Mohamad Zaidin Mohamad, Tengku Fatimah Muliana Tengku Muda

To Link this Article: http://dx.doi.org/10.6007/IJARPED/v8-i2/5828

DOI: $10.6007 /$ IJARPED/v8-i2/5828

Received: 16 Jan 2019, Revised: 21 Feb 2019, Accepted: 16 March 2019

Published Online: 21 April 2019

In-Text Citation: (Istikomah, Abdullah, Daud, Mohamad, \& Muda, 2019)

To Cite this Article: Istikomah, Abdullah, A. H., Daud, N., Mohamad, M. Z., \& Muda, T. F. M. T. (2019).

Homeschooling Effectiveness in Cultivating Islamic Values for Children (A Case Study at Mutiara Ummah Sidoarjo Homeschooling). International Journal of Academic Research Business and Social Sciences, 8(2), 298-306.

Copyright: (c) 2019 The Author(s)

Published by Human Resource Management Academic Research Society (www.hrmars.com)

This article is published under the Creative Commons Attribution (CC BY 4.0) license. Anyone may reproduce, distribute, translate and create derivative works of this article (for both commercial and non-commercial purposes), subject to full attribution to the original publication and authors. The full terms of this license may be seen

at: http://creativecommons.org/licences/by/4.0/legalcode

Vol. 8(2) 2019, Pg. 298 - 306

http://hrmars.com/index.php/pages/detail/IJARPED

JOURNAL HOMEPAGE

Full Terms \& Conditions of access and use can be found at http://hrmars.com/index.php/pages/detail/publication-ethics 


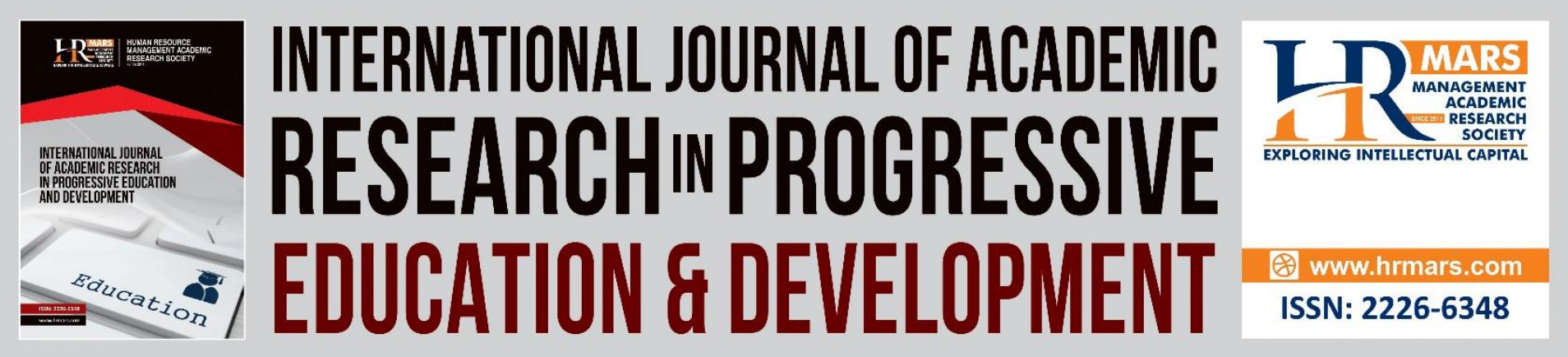

\title{
Homeschooling Effectiveness in Cultivating Islamic Values for Children: A Case Study at Mutiara Ummah Sidoarjo Homeschooling
}

\author{
${ }^{1}$ Istikomah, ${ }^{2}$ Abdul Hakim Abdullah, ${ }^{2}$ Normadiah Daud, ${ }^{2}$ Mohamad \\ Zaidin Mohamad, ${ }^{2}$ Tengku Fatimah Muliana Tengku Muda \\ ${ }^{1}$ Islamic Faculty, Universitas Muhammadiyah Sidoarjo Indonesia \\ ${ }^{2}$ Faculty of Islamic Contemporary Studies, UniSZA, Malaysia
}

\begin{abstract}
Giving the best education to a child is every parent's aspiration. In Islam, children are regarded as a bounty, a gift and a trust from Allah,to be educated and guided as well as possible. Nevertheless, recently there have been issues on parents' dissatisfaction over the public sector schools' system owing to increased social problems and negative behaviors among students such as involvement in drugs, premarital sex and bullying. Alternately, homeschooling system is created as an alternative to the public school setting. This research was conducted at Homeschooling of the Mutiara Ummah Community in Sidoarjo through qualitative method and using case study approach. Data were collected using observation, documentation, and in-depth interviews. Data were then analyzed in three stages, namely data reduction, display and conclusion. The research subjects include homeschooling manager, headmaster, tutors, students and parents. The purpose of this paper is to analyze the effectiveness of homeschooling in instilling Islamic values to the children. Based on the results of the study, it can be concluded that the curriculum design of homeschooling in Mutiara Ummah Community is effective to cultivate and instill Islamic values for children. The curriculum is designed independently which contains Islamic values (faith, worship, and relationship), Quran memorization, knowledge and skills, as well as community program. The desired outcomes of homeschooling are the cultivation of superior Muslim personalities as well as gaining personal skills in accordance with certain area of expertise.
\end{abstract}

Keywords: Effectiveness, Homeschooling, Islamic Values

\section{Introduction}

Education is an important dimension for survival of human life. The education process is generally carried out in educational institutions called schools. However recently, issues concerning public school have caught the attention of many parents. Perceived dissatisfaction are said to be out of the schooling system, curriculum design, and learning method which resulted from failure of the school sector to meet the high expectations of parents, especially in cultivating religious values, 
moral and shaping personality for students. Schools are naturally more report cards oriented, rather than focusing on the development of personality, skills and bridging social relations. While it is generally perceived that smaller size of classes are associated with increased student achievement and better learning experience, school classes often reaches 30 students and above, affecting the students-teacher interactions. The expected results in the education process are positive changes in attitudes, knowledge and skills of the students. Since parents are the first and foremost educators, it is not uncommon for parents to expect the best education for their children (Ali, 2010).

In a family institution, parents have high responsibilities over the child's growth and development, to teach social and religious values for their children as emphasized by Suprayitno. The current social problem and deviant behaviors of school students such as involvement in drug and alcoholic drinks, premarital marriage, bullying or brawling, caused frustration and dissatisfaction among the concerned parents. While the educational practice at schools today runs at very fast pace, students are forced to absorb as much knowledge as possible amidst the intense curriculum content. Students are merely required to memorize the contents without understanding the meaning of memorized material. There is no intense dialogue or communication process between students and teachers. This kind of learning process inhibits students' creativity. Students are burdened with tasks that they are unable to apprehend. In addition, since schools normally result oriented rather than focusing on the learning processes, students, teachers and institution managers would justify any means to achieve high grades. Looking at the phenomenon above, it is necessary to have an educational alternative that can accommodate parents' wishes.

In 2005, Indonesia has developed a family-based educational institution known as homeschooling. This institution is an informal educational institution based at home, placing students with home approach by using house as the main place for learning with very flexible learning hours (Permana, 2012). In contrast to formal school system, homeschooling emphasizes the process and results. The curriculum is designed in accordance with parents' inclination which emphasized on noble character building and appropriate skills that suited the students' talents and interests. The emergence of this institution is based on parents' dissatisfaction with formal schools. One of the reasons behind parents choosing homeschooling is flexibility to instill Islamic educational values and develop the children's potential.

Formal school systems do not offer many roles to parents. Children are too tired of the existing curriculum that their individual potential cannot be channeled. Parents who are aware of their children's potential and wishes to be involved in their children's education and development shall prefer homeschooling than formal schools. Homeschooling seems to them offering the children with a lot more opportunities to explore their potential. The presence of Mutiara Ummah Homeshooling which located at J. Arjuna Kebon Sari Candi Sidoarjo was founded on parents' concerns and anxiety over the results of general education such as provided by elementary schools which did not prioritize instilling Islamic values which of one crucial element in Islamic education. The importance of Islamic education for children is also recognized by the government. Therefore, Islamic education must be provided in various educational institutions starting from elementary level to college (Saleh, 2000).

Out of the children's potential, there is a need for parents to develop the spiritual potential and embedding Islamic values in the children which are based on the Qur'an and Hadith. Instilling 
INTERNATIONAL JOURNAL OF ACADEMIC RESEARCH IN PROGRESSIVE EDUCATION AND DEVELOPMENT

Vol. 8, No. 2, 2019, E-ISSN: 2226-6348 @ 2019 HRMARS

Islamic values through education aimed at shaping Muslim's generations who are balanced in faith, intelligence, emotional and spiritual development. From the Islamic perspective, the main education is family (Tafsir, 2001), which aims to form the children to become faithful human beings, devoted to Almighty Allah and noble by balancing intellectual, emotional and spiritual intelligence. This exemplifies the behavior of the Prophet Muhammad PBUH and his companions in fostering his family, as stated in the al-Quran in Surah al-Tahrim verse 6.

Every child is born in a state of fitra (natural disposition), so their parents make them a Jew, Christian or Magian. The presence of homeschooling in Indonesia has a strong legality as regulated in the national education system No. 20 of 2003 and has been elaborated in a ministerial regulation. It is also based on the functions and objectives of national education, namely to develop students potential become believers and fear of Almighty Allah, noble, intelligent, creative, democratic and responsible citizen.

\section{Methodology}

This is qualitative research with a case study approach. This research studies, analyzes, explains and interprets a case in a natural context. By employing the method, researcher has an opportunity to control the events under study and focus the problem on the context of real life (Yin 1996). This research is carried out in conditions and situations where there is no limit in interpreting and understanding phenomena and is carried out in natural situations. The research subjects are the principal, teachers, students, and students guardian of in Homeschooling Mutiara Ummah Community in Candi Sidoarjo Indonesia. The methods of collecting data in this research are through participant observation, interviews and documentation. After the data collected, they were then analyzed with descriptive analysis, namely the conclusion of an object in the form of thoughts, actions and systems that relate to phenomena systematically and factually. Data analysis methods are carried out interactively as formulated by Hubermen and Miles (1992) through three stages, namely data reduction, data display and conclusion drawing.

\section{Results}

According to Sumardiono (2007) the term Homeschooling derives from English which means home school. Homeschooling is a teaching learning proces that is organized through planned activities with the home as the main center of learning and parents as teachers or supervisors. Magdalena (2010) statesd that substantially homeschooling has the meaning of independence in the implementation of education in the family, where the material is selected and adapted to the needs of children. Thus homeschooling serves to develop the potential of students with an emphasis on mastering knowledge, skills and the development of attitudes and personality. Homeschooling is also referred to the term "home education" or home-based learning. Meanwhile the Ministry of National Education in Indonesia uses the term "home school" or independent school.

This institution is an alternative education model managed by families, or private institution with flexible rules, so that students can develop according to their potential. This home-based education has actually been implemented for thousands of years throughout the world, because school-age children have just attended education in the new institution in 1900 (Ray, 2017). The appearance of the term home schooling derives from United States in 1960 by John Caldwell Holt, with basic thought that education in schools is more capital, because education is made as a 
project. In 1996 Homeschooling in America has grown to reach 15\% every year and even has spread to Europe and Asia, Blumenfeld (1984) . In 2016 a non-formal school model appeared called worldschooling, which is an educational model whose teaching and learning materials are not in the classroom, but using traveling and real world as material and learning facilities (Riley 2017).

As far as Indonesia is concerned, homeschooling grew in 2005 which was motivated by the presence of public schools that were not evenly distributed in each region. On the other hand, the establishment of homeschooling offers options in education system that is reserved for talented children who have special potential. Homeshooling in Indonesia now mostly grows and develops in big cities, due to parents' awareness on the importance of education (Kurniasih 2009).

The existence of homeschooling in Indonesia has developed long time ago before independence, however, it was then termed as "panggulowentah". For example it could be seen from the Father of Indonesian Education, namely Ki Hajar Dewantara who applied homeschooling in Taman Siswa, a successful figure who does not have formal education background. In practice, homeschooling in Indonesia has three features including: (1) single homeschooling, (2) multiple homeschooling, (3) community homeschooling (Seto 2007). Single homeschooling is homeshooling that is carried out in families and it does not join other institutions. Parents are responsible as the main teachers. Paid teachers are only invited to develop the children's talents. Multiple homeschooling on the other hand, is very different from a single homeschooling. It is carried out by two or more families, where education and learning activities are still carried out in each family, using a curriculum design that is almost the same. Meanwhile homeschooling community is a collection or combination of multiple homeschooling, so it has the same syllabus, curriculum, schedule, and study days.

Homeschooling communities have implemented standard contents of education, based on National Education Standards. Out of 13 aspects of standard content, there are five (5) different aspects of planning and management compared to formal schools in general. The aspect in question is; (i) aspects of curriculum content (ii)aspects of curriculum development, (iii) face-toface aspects, (iv) aspects of syllabus development and, (v) aspects of RPP (lesson plan) development. The content aspect of the homeschooling community curriculum does not follow the provisions of national standards, it has the curriculum content based on the standardization of its independent curriculum (based on the Islamic aqidah and the needs of students). The primary aspect of curriculum development involves only the head of the community homeschool, tutors / teachers and parents of students. From the face-to-face aspects, community homeschooling learning duration is determined to be less than 40 minutes, and carried out on the day agreed by students and tutors, or carried out according to the needs of students (flexible). From the aspect of learning environment, it is not only limited to take place in the classrooms, but it can also have other learning environment suiting the teaching theme. The aspect of developing the syllabus and RPP (lesson plan) are only executed by tutors or teachers.

Organizing homeschooling in Indonesia is legal, because it has been regulated in the National Education System Law No. 20 of 2003 which stated that the implementation of education in Indonesia shall be implemented in three ways, namely : formal, non formal and informal (education in the family). It is also regulated under Permendikbud (Minister of Education and Culture Regulation) No. 129 of 2014 on home school. By then, Minister of Education and Culture was 
headed by M. Nuh. Article 1 paragraph 1 of the regulation provide that home school is an educational process that is consciously and planned carried out by parents or family at home or other places in a single form, multiple and community, where the learning process can take place in an atmosphere which is conducive with the aim that each unique student's potential can be optimally developed.

Homeschooling Mutiara Ummah is an Islamic-inspired school, under the institution of AlIkhlas which is located at Jl. Arjuno Kebon Sari Candi Sidoarjo. Based on the observations and interviews, Mutiara Ummah Homeschooling is a homeshooling that implement six-year basic level education. It has been legalized as formal school in general, since the students were registered at the main school named SD Nurul Huda at Sencaki street number 64 Surabaya. As a result, the students are able to join the package ' $A$ ' equation test which enables them to get a certificate as other formal schools after graduation. It is the interest of the paper to describe and analyze the effectiveness of learning model implemented in Mutiara Ummah Homeschooling which emphasizes on the cultivation of Islamic values among the students. In achieving the purpose, several aspects were analyzed, namely:

\section{a. Curriculum Aspects.}

Almost all homescholing curriculum in Indonesia have different curriculum standard. Each homeschooling has a distinct style, this is due to the basic nature of home schooling itself that has access to open information as well as freedom of the parents to design the curriculum (Razi 2016). Homeschooling Mutiara Ummah as a community homeschooling which combinates multiple homeschooling, the curriculum and teaching materials are arranged systematically containing : syllabi, teaching materials, lesson schedules, core activities and others. Curriculum design at Homeschooling Mutiara Ummah Community prioritize memorization of the Quran (Tahfidz Al-Qur'an) with a minimum target of 3 juz, BTQ (Read Write al-Qur'an), Arabic and noble moral guidance. Other general courses such as Math, Indonesian Language, Science, social studies, sports are also taught, as well as an extra curriculum in accordance with the interests and talents of their students. For extra parental curriculum, parents can invite tutors in accordance with their expertise. Because homeschooling is a type of community, the curriculum design is carried out by parents, principals and tutors or teacher. The curriculum is integrated with the National Education Department, since at the end of the sixth grade students shall be taking the National Standard National Examination to get a certificate in the equivalent of package A under the main school; SD Nurul Huda Surabaya.

\section{b. Learning Strategies}

As a family based school that prioritizes growth and children's rights, the learning strategy is designed in an attractive approach. In general, even though there is classical learning in home schooling community, the class size shall not exceed 10 students. The main aim of homeschooling is to provide effective guidance and education services for students and to maximize the potential of students. Subsequently, Mutiara Ummah Homeschooling Community only cater 55 students from first to sixth grade level, with each class or level consisting between 5 to 10 students only. The learning strategies include (a) turorial community, that is students will learn certain subjects according to their level. Classical learning is held on Monday until 
INTERNATIONAL JOURNAL OF ACADEMIC RESEARCH IN PROGRESSIVE EDUCATION AND DEVELOPMENT

Vol. 8, No. 2, 2019, E-ISSN: 2226-6348 C 2019 HRMARS

Thursday. The classical learning objectives are to enable the students to experience school atmosphere, but conceptualized with joyful learning activities which include play model and reward games; (b) outdoor learning, namely learning outside the classroom with natural (tadabur), for examples students are invited to the garden and rice fields during science course on the topics of plants; students are also encouraged to practice storytelling which will be presented in front of the class and invited to the nearest radio station as to improve their language skills. With tadabur alam, students can observe, ask questions, collect information, associate and communicate to the teacher and his parents; (c) home visit where tutor or teacher is invited to their home to develop certain skills in accordance with the interest of the students. However as to date, only four (4) families opt to invite tutors in the children's learning process (d) student centered learning process, whereby the students can interact with the real world and the teacher-student interaction is closer, this approach will also enable the the tutor to better understand the character of each student. Homeschooling, according to Kunzman will bring children to study in the real world and in a very open nature.

c. Study Time

As a family based education, homeschooling yields for more responsibility of the parents towards the children. Parents also get to be more involved in learning activities with their children. Mutiara Ummah Homeschooling is a community homeschooling, where several families gather to conduct joint activities under a non-profit organization called "Yayasan AlIkhlas". Parents here do not entrust their children to the institution, yet parents themselves will be directly involved in planning, implementing and evaluating the process education and teaching. Because of the nature of the community, the students have their own study groups in the form of community tutorials where the students are taught with subjects that have been planned in advance according to their respective levels. This Community Tutorial is held 4 times a week from Monday until Thursday, at 07:30 am until $13.15 \mathrm{pm}$. This activity is carried out with the aim that students can experience the school atmosphere through interaction and fun socialization with their school friends. Since Homeschooling Mutiara Ummah has a vision to create a generation of intelligent Muslims with a noble character, most of learning hours are filled with the cultivation of Islamic values activities. The learning schedule is arranged as follows: from 07:30am until $08.00 \mathrm{am}$, students will perform daily prayers, 08.00am to 09.00am, Tahfidz al-Qur'an, at 09.00am to 09.30am, student to perform congregational Dhuha Prayer, at 09.30am to $11.40 \mathrm{am}$, students will learn general courses namely Mathematics, Indonesian Language, Science, Geography, Arabic and Art, at 11.40am to 13.15 pm, students to perform Dzuhur prayers together, commendable qabliyah and ba'diyah prayers and lunch, and at 12.30pm to $13.15 \mathrm{pm}$ will be spent for Tahfidz Quran activity.

\section{d. Evaluation}

Evaluation in the community homeschooling institution is not simply done by giving a score in the form of numbers in the report card, rather, the evaluation aims to see whether the family vision has been practiced in learning activities in community homeschooling. The evaluation techniques at the Mutiara Ummah homeschooling are carried out by tutors and parents through their observation of daily processes which include cognitive, affective and psychomotor aspects 
of their children or students. The most important assessment is on the students' ability to behave in accordance with Islamic values with the tahfidz program as its superior program. However, since the students undertake the package A equation test, the academic assessment shall include Middle Semester Examination (UTS) and Final Semester Examination (UAS). The examination questions and report cards are made by themselves and the examination schedule is different from the main school's.

\section{Conclusion}

Homeschooling community as a family based education and is very effective in cultivating Islamic values. There are several indicators that can be used as measures including:

a) The curriculum is adapted to the vision and mission of the family.

b) The determination of the school day depends on the parents' agreement.

c) Learning is very practical and effective since one class shall not exceed 10 students.

d) Learning atmosphere take place inside and outside the classroom based on real experience.

e) Close relationship between the teacher and students, as in the relationship between parents and their children.

f) Students who yet to complete their studies will receive personalized service.

g) Evaluation is carried out based on processes in the form of positive changes in attitudes, behavior and real knowledge.

The forms of planting Islamic values include:

a. The main curriculum is Tahfidz al-Qur'an, Ibadah (relationship between human and God) and Muamalah (relationship between human and human).

b. In classical learning, Islamic disposition is always instilled.

c. All teaching materials delivered to students are sourced from al-Quran and Hadith, whether it relates to social, humanities, arts or other.

d. Curriculum design includes an outdoor or tadabur learning, which aims to admire the power of God and strengthen the faith of students.

e. Learning assessment is not only based on mastery of the material, especially the memorization of al-Quran, but more on changes in attitudes and behavior in accordance with Islamic values that have been accustomed in daily life.

f. There is a communication book that contains reports on students' activities at home related to daily worship called 'The Contact Book'. This book is filled by parents and teachers.

\section{Acknowledgment}

This research was supported by the Muhammadiyah University Sidoarjo. We would like to extend our gratitude to all lecturers at the Islamic Faculty at Muhammadiyah University Sidoarjo who have helped in completing the research. Appreciation also goes to the al-Ikhlas Institution for the permission given in conducting the research. The results of this research are expected to be a reference for parents in choosing the best education for their children and also for school managers namely "Yayasan al-Ikhlas". 
INTERNATIONAL JOURNAL OF ACADEMIC RESEARCH IN PROGRESSIVE EDUCATION AND

DEVELOPMENT

Vol. 8, No. 2, 2019, E-ISSN: 2226-6348 @ 2019 HRMARS

\section{References}

Tafsir, A. (2001). Educational Science in Islamic Perspective. Bandung: Remaja Rosda Karya.

Ali, M. D. (2010). Islamic Education. Jakarta: Raja Grafindo, Persada.

Blumenfeld, S.L. (1984). N.E.A.: Trojan Horse in American Education. Boise, ID: The Paradigm Company.

Yin, R. K. (2009). Case Study Research Design and Methods. Jakarta: PT. Rajawali.

Kurniasih, I. (2009). Homeschooling. Jogyakarta : Penerbit Cakrawala.

Magdalena, M. (2010). My children Don't Want to Go to Schools Don't Be Afraid Try Homeschooling. Jakarta: PT Gramedia Pustaka Utama.

Huberman, M. \& Miles, M.B. (1992). Qualitative Data Analysis. Trans. Tjetjep Rohendi Rohidi. Jakarta: UI Press.

Hassan, A.B. \& Khairuldin, W. M. K. F. W. (2019). Smart Quran Application: Authority of Digital Mushaf Usage in Malaysia. International Journal of Civil Engineering and Technology, 10(3). pp. 3315-3322.

Khairuldin, W. M. K. F. W., Anas, W. N. I. W. N., \& Embong, A. H. (2018). Experts' View within Fatwa Production in Malaysia. International Journal of Academic Research in Business and Social Sciences, 8(11), 530-538.

Khairuldin, W. M. K. F. W., Embong, A. H., Anas, W. N. I. W. N., Mohd, H. \& Ismail, D. (2018), The Application of Technology in the Dissemination of Fatwas: A Study on Religious Institutions in Malaysia, International Journal of Civil Engineering and Technology, 9(7), 2018, pp. 15901596

Mulyadi, S. (2007). Homeschooling by Kak Seto Family: Easy, Cheap, Festive, and Approved by the Government. Bandung: Kaifa PT Mizan Pustaka.

Ray, B. (2017). A review of research on homeschooling and what might educator learn. ProPosicoes. 28(2): 85-103.

Razi, A. (2016). Homeschooling: An alternative education in Indonesia. International Jounar Nusantara, Vol. 04, No. 02, 2016

Riley, G. (2017). Worldschooling: Homeschooling away from home. International Journal of Education. 9(1): 186-191.

Saleh, A.R. (2000). Religion Education and Religious. Jakarta: PT Gema Windu Pancaperkasa.

Permana, S.E. (2012). Family Education is a Lifelong Educational Resource. Pekalongan: Edukasia Pres.

Sumardiono. (2007). Homeschooling, the Leap of Learning. Jakarta: PT. Elex Media Komputindo. 